\section{Effect of Haemoglobin on Experimental Infections with Pasteurella septica and Escherichia coli}

Вотн haematin hydrochloride and ferric ammonium citrate can abolish the protective effect of immune serum in experimental infections with Pasteurella septica in mice $^{1}$. Ferric ammonium citrate has the same effect with Clostridium welchii Type $A$ infections in guinea-pigs ${ }^{2}$. The importance of these observations depends on the fact that iron can abolish the bacteriostatic effect of sera against $C t$. welchii in vitro ${ }^{3}$. Because iron compounds seem to have such similar effects both in vitro and in vivo, it seems quite likely that the bacteriostatic action of serum may play an important part in resistance to bacterial infections.

We find that homologous lysed red cells as well as heterologous crystalline haernoglobin are effective in abolishing passive immunity to $P$. septica. Homologous lysed red cells and crystalline haemoglobin also enhance the virulonce of Escherichia coli (type 0111B4) in normal guineapigs.

Red cells wore prepared from blood withdrawn from the tails of anaesthetized mice; they were separated by centrifugation, washed three times with normal saline and lysed by the addition of approximately 5 volumes of distilled water. The cell stroma was removed by centrifugation and tho supornatent fluid sterilized by filtration through a Seitz $E K$ pad. The haomoglobin in the filtered solution was measured colorimetrically by the carboxyhaemoglobin (Haldane) method. Lysed guinea-pig cells were prepared in the same way as lysed mouse cells except that the blood was removed by cardiac puncture from animals anaesthetized with other. Chromatographically homogeneous haemoglobin was isolated from human blood by the mothod of Allen et al. ${ }^{4}$ and the solution sterilized by filtration through a cellulose ester membrane (Oxo, Ltd., London). Crystalline human haemoglobin was prepared from the same sample of blood by the method of Drabkins. Two samples of crystalline horse haemoglobin were used (twice recrystallized grado $A$, Calbiochem; and Koch-Light Laboratories). The haemoglobin solutions were sterilized by filtration through a Seitz $E K$ pad. The lysed red cells and the haemoglobin solutions were mixed with the bacteria immediately before intraperitoneal injection.

The methods of passive immunization, and infection with $P$. septica (strain $C N \quad 3449$, Wellcome Research Laboratories), were the same as those described proviously ${ }^{1}$. For all the experiments the dose of bacteria injected intraperitoneally varied between $1.5 \times 10^{5}$ and $2.9 \times 10^{6}$, but in any individual experiment the treated and control groups received identical numbers of organisms. The effects of lysed mouse red cells (oquivalent to 7-28 mg haemoglobin) and the purified haemoglobins on passive immunity against $P$. septica are shown in Table 1 . None of these compounds was toxic to normal mice.

$E$. coli strain $0111 B 4$ was passaged in guinea-pigs by the same technique used for mice, but the lethal dose $\left(>3 \times 10^{7}\right.$ organisms) for guinea-pigs weighing $250-300 \mathrm{~g}$ remained relatively high. For the experiments with lysed

Table 1. EFFECT OF LYSED MOUSE RED CELLS AND PURIFTED HAFMOGLOBINS ON INFECTION BY $P$. septica (STRAIN CN 3449) IN PASSIVRLY IMMUNIZTIS

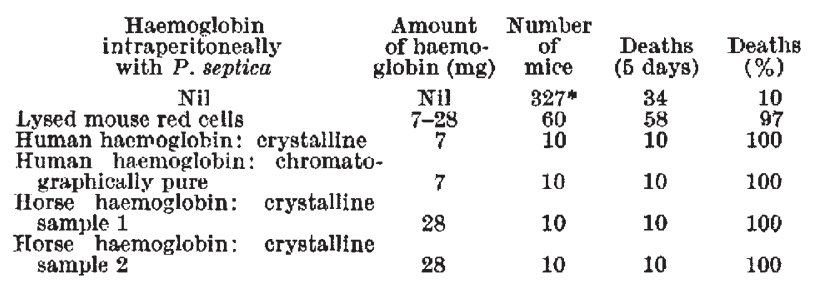

* Including controls from other experiments.
T'able 2. FEFECT OF LYSED G UINEA-PIG RED CRLIS AND CRYSTALLINE HARMOGLORIN ON INFECTION BY $E$, coli (STRATN 0111B ) IN NORMAL GUINBA-PIGS

\begin{tabular}{|c|c|c|c|c|}
\hline $\begin{array}{l}\text { Haemoglobin } \\
\text { intrapcritoncally } \\
\text { with } E \text {. coli }\end{array}$ & $\begin{array}{l}\text { Amount } \\
\text { of haemo- } \\
\text { globin (mg) }\end{array}$ & $\begin{array}{l}\text { Number } \\
\text { of guinea- } \\
\text { pigs }\end{array}$ & $\begin{array}{c}\text { Deaths } \\
\text { (3 days) }\end{array}$ & $\begin{array}{c}\text { Deaths } \\
(\%)\end{array}$ \\
\hline 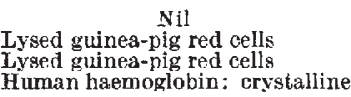 & $\begin{array}{c}\mathrm{Nil} \\
166-236 \\
50 \\
135\end{array}$ & $\begin{array}{l}25 \\
30 \\
15 \\
10\end{array}$ & $\begin{array}{r}0 \\
29 \\
8 \\
9\end{array}$ & $\begin{array}{r}0 \\
97 \\
53 \\
90\end{array}$ \\
\hline
\end{tabular}

red cells and haemoglobin shown in Table $2,2 \cdot 5$ to $6 \cdot 6 \times 10^{4}$ L'. coli were injected intraperitoneally. Neither the lysed cells nor the haemoglobin solution was toxic to normal guinea-pigs.

It is clear that homologous lysed red cells and a variety of purified haemoglobins can be effective in abolishing passive immunity to $P$. septica in mice, and enhance the virulence of $E$. coli in normal guinea-pigs. The mechanism of these reactions needs further investigation, but for the moment we have assumed, in the case of $P$. septica at least, that the reason for the effectiveness of these compounds is connected with the ability of the bacteria to acquire iron from the haemoglobin molecule. This is based on the observation that ferric ammonium citrate, a relatively simple iron compound, produces the same effect as haematin and haemoglobin. Whether the presence of free haemoglobin in wounds or infected tissue might play a part in encouraging bacterial infection is a matter for speculation, but it seems to be a possibility.

\section{J. J. Bullex}

Rowett Research Institute,

HenRy J. Rogers

Bucksburn, Aberdeen.

Received September 11; revised October 16, 1967.

' Bullen, J. J., Rogers, H. J., and Cushnle, G. H., Nature, 214, 515 (1067).

s Bullen, J. J., Cushnie, G. H., and Rogers, H. J., Immunology, 12, 303 (1967),

" thogers, H. J., Immunology, 12, 285 (1967).

- Allen, D. W., Schroeder, W. A., and Balog, J., J. Amer. Chem. Boe., 80 1628 (1958)

Drabkin. D. L., Arch. Biochem., 21, 224 (1949).

\section{Mechanism of Closure of the Aortic Valve}

THE human aortic valve consists of three cusps made of relatively inelastic, muscle-free material about $0.15 \mathrm{~mm}$ thick. It opens and shuts about once a second, and withstands a pressure difference of $100 \mathrm{~mm}$ of mercury when closed. It usually functions for $70 \mathrm{yr}$ without failure, and works so efficiently that very little blood is regurgitated at each pulse. In order to support this large

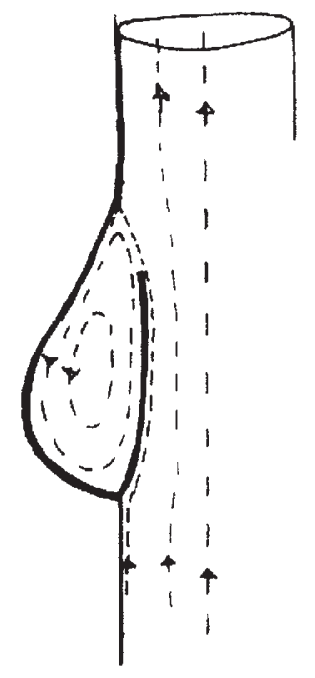

Fig. 1. Vortex formation in a sinus. 